\title{
Creativity in Gifted Education: Contributions from Vygotsky and Piaget
}

\author{
Tania Stoltz, Fernanda Hellen Ribeiro Piske, Maria de Fátima Quintal de Freitas, \\ Marlene Schüssler D’Aroz, Járci Maria Machado \\ Federal University of Paraná, Curitiba, Paraná, Brazil \\ Email: nandahellen@hotmail.com
}

Received 9 December 2014; accepted 20 December 2014; published 14 January 2015

Copyright (C) 2015 by authors and Scientific Research Publishing Inc.

This work is licensed under the Creative Commons Attribution International License (CC BY). http://creativecommons.org/licenses/by/4.0/

(c) (i) Open Access

\begin{abstract}
This research aims to highlight the importance of developing creativity in the school environment by promoting quality education to gifted students, with contributions from Vygotsky and Piaget. For Vygotsky creativity is inherent in the human condition, and it is the most important activity because it is the expression of consciousness, thought and language. It is the highest expression of subjectivity (Vygotsky, 2010). According to Piagetian theory, Stoltz (2013) points out that although the source of creativity is a mystery to Piaget, it manifests itself doubly: in the construction of knowledge structures and construction of real or structure and cognitive functioning. The method of this research is a bibliographic study of the area of high ability/giftedness, the cultural-historical theory of Vygotsky and Piaget's genetic epistemology. We conclude that for Vygotsky (2008) as well as for Piaget (1968) the environment has essential importance to the development of creative potential. In the environment the child has his/her experiences that stimulate curiosity, desire to learn, fantasy and imagination. The teacher should enable gifted students to share their high abilities with their couple performing challenging activities in a stimulating and responsive environment.
\end{abstract}

\section{Keywords}

Gifted Students, High Ability

\section{Introduction}

This study aims to highlight the importance of developing creativity in the school environment by promoting quality education for gifted students, with contributions from Vygotsky and Piaget. Recent studies using different methods and theoretical approaches have indicated that gifted and high ability people are extremely creative

How to cite this paper: Stoltz, T., Piske, F. H. R., de Freitas, M. F. Q., D’Aroz, M. S., \& Machado, J. M. (2015). Creativity in Gifted Education: Contributions from Vygotsky and Piaget. Creative Education, 6, 64-70.

http://dx.doi.org/10.4236/ce.2015.61005 
(Alencar, 2001, 2007; Peterson, 2003; Renzulli, 2004; Pérez, 2004; Piske, 2011, 2013; Piske \& Stoltz, 2012, 2013; Prieto, Soto, \& Fernandez, 2013, Piske, Stoltz, \& Machado, 2014a, among others). On the other hand, the literature has indicated that schools have difficulty in working to develop this characteristic (Winner, 1998; Alencar, 2001, 2007, 2009, 2011; Piske \& Stoltz, 2013; Piske, Stoltz, \& Machado, 2014b, among others). In the view of these authors, schools have shown themselves to be monotonous, using repetitive activities requiring reproduction of knowledge rather than the production of new knowledge. A widespread lack of preparation can be seen among teachers towards developing creativity at school. Development of creativity is essential, especially in a globalized world in which information is available everywhere, and schools urgently need to keep pace with this if they are not to lose their raison d'être.

What do Piaget and Vygotsky have to offer to the discussion in question? Both express the ideational movement of their time, of the modern age, at the same time going beyond their time. The intention is to understand creativity based on these two great theoretical authors, as well as the possibilities, based on these theories, for the education of high ability/gifted people. The theoretical discussion proposed in this study involves the area of high ability/giftedness, Vygotsky’s cultural-historical theory and Piaget’s genetic epistemology and psychology. This is justified based on the understanding that creativity should be the driving force of educational efforts, which in turn implies greater integration of art and its different manifestations in schools (Stoltz \& Weger, 2012; Marjanovic-Shane, Connery, \& John-Steiner, 2010).

\section{Educating for Autonomy as Educating for Creativity in Piaget}

Despite Piaget strongly expressing that he did not have a fixed opinion about Pedagogy, the problem of education interested him intensely. Aware of the impossibility of the direct transposition between the data of his Genetic Epistemology and Psychology and education, he calls on pedagogues to develop and adjust techniques for a proposed form of active teaching. Piaget's proposal aims to offer a series of devices for child experimentation and invention. Children would be guided through this process. In the words of Piaget,

Education, seen from the current viewpoint, consists of attempting to transform children into the kind of adults existing in the society to which they belong. (...) Whereas for me education consists of producing creators, even if there are not many, even if the creations of one are limited in relation to those of the other.

But the need exists to produce nonconformist inventors, innovators. (...) In different degrees, of course: but there is always a domain in which it can exist (Piaget in Bringuier, 1978: p. 183)... the great mistake made by some, was to go ahead with formalization before the time was right, with school students who, in no way whatsoever, had a method to assimilate (Piaget in Bringuier: p. 180).

Contribute to the development of creators: that is the translation of education into the development of autonomy in Piaget. Although the origin of creativity remains a mystery for Piaget, or the origin of talent, the most mysterious secret, Piaget understands cognitive development to be an essentially creative process. This form of understanding does not deny reality, but rather indicates that the problem of knowledge lies in the manner in which a person reconstructs reality. "Reality needs to be known, of course, but it needs to be reduced, through deduction and endogenous construction" (Piaget in Bringuier: p. 155). In this interactive and constructive process between the body and the environment, a new organ is created (cognitive structures) which regulates the exchanges between the body and the environment (Piaget, 2003). In order to be built, cognitive structures depend on coordination between the following factors: organic maturation, as a condition of that which the body is capable of; experience with physical objects; social experience and the self-regulating balancing process which coordinates the remaining factors (Piaget, 1936, 1937, 1964; Piaget \& Inhelder, 2003).

When Piaget sees the need to pay special attention to spontaneous development, he is not referring to that which is a product of empty verbalism, but to the coordination of social experience, physical experience and maturation through the organismic self-regulating equilibrium process, which is essentially creative but not voluntary. Here we have an impasse: the aim of education is the development of autonomy, which in turn requires its own determination of the routes of its formation (Piaget, 2000).

However, the result of a person's creations depends, in the final analysis, on the equilibrium process, which is not voluntary. There are, therefore, internal limits in relation to that which is built autonomously through interaction with the environment. Grasps of consciousness, as conceptual reconstitutions of what occurred in actions, represent the very domain of autonomy and creation in Piaget (1974a, 1974b). It represents an autonomous 
self-regulated process. In actions, understanding is concentrated on the object and not on the mechanisms that made it possible to reach it, whereas grasp of consciousness involves interpretation and explanation of actions. Where is creativity here? It is in the manner in which a person rebuilds their actions, or in the production of more powerful logical structures "that permit the individual to act upon the world in more flexible and complex ways” (Gruber \& Vonèche, 1995: p. xxxix).

Piaget notes that autonomy of thought is only possible with effect from the formal operatory stage. With regard to cognitive structures based on rational logic and which imply new ideas, small children work with very limited possibilities and needs; whereas adolescents can see infinite possibilities which require necessary integrations. Nevertheless, Piaget notes that the period in which human cognition is most created, in terms of rapidness and fecundity, is between birth and eighteen months, prior to language, and takes the form of intelligence in action (Vonèche \& Stoltz, 2007). Later, everything will be rebuilt on the level of thought and representation on the conceptual plane. For example, on the plane of representation, symbolic play's own imagination allows imaginary situations to be invented and which have unconscious affective impulses. In symbolic play, the peak of childhood play, creations are the result of reality's submission to the needs of self (Piaget, 1978).

Piaget states that finding new ideas depends, first of all, on not reading anything about the subject and letting all ideas flow, however absurd they may appear. Following this, it depends on reading everything about the subject and having a target for exercising critique ("Tête de Turc") (Bringuier, 1978). Creative imagination can thus be perceived to be at the origin of novelties, but that in order for it to advance, it has to be integrated into rational logical thought. In the construction of the new, creative imagination and rationale maintain a relationship of interdependence in cognitive development and are related to openings (possible) and closings (necessary) (Stoltz \& Parrat-Dayan, 2012; Stoltz, 2013).

Affectivity is the driving force of action in Piaget and, with the development of rational logic, moves from undifferentiation to differentiation and later integration of different points of view. A similar movement can be seen in relation to morality which, starting from anomy, goes on to heteronomy and then to autonomy, although this is never completely achieved, which is expressed in ideal or supra-individual values. Piaget sees the creative process of construction in all these dimensions of the human being. Like the physicist Niels Bohr, it is Piaget's understanding that we are tied and that we start from the description we give to the universe, which is relative to that to which we have access and which through our human and biological constitution we are able to assimilate. This is equivalent to recognizing our position in that which we do. On the other hand, this position puts us in the situation of creators. In this case, the description of human creativity, in Piaget, takes into consideration the agreement between mathematics and reality.

For me, mathematics is in nature-nature including human reason-and the latter, elaborating mathematics with a body and a nervous system, with all the body that is peculiar to it, which forms part of physical nature, in such a way that there is an agreement between mathematics and reality, through the body, and not through physical experience supported by objects (Piaget in Bringuier, 1978: p. 151).

Thus creativity is essentially found imbedded in the precisely human construction of cognition via interaction with the world. Cognition is neither a copy of reality, nor the result of genetic preformism. In this process, construction of intelligence and construction of reality represent the two poles of a single creating unit that structures the universe. People create their structures and reality based on interactive exchanges with the environment and, in this way, get increasingly closer to reality. In this sense, for Piaget, to invent is also to circulate between disciplines. In this way, Piaget indicates the interdisciplinary character of the innovations he dedicated himself to studying: scientific creations. These are basically explained by Piaget's interaction, construction and logical determinism.

\section{Creative Education for the Production of Meaning in Vygotsky}

Differently to Piaget, throughout his entire life Vygotsky had personal and scientific interest in the domains of literature, theatre, art and literary criticism. According to Van der Veer and Valsiner (2009), this is the social and personal context related to Vygotsky having turned to Psychology, after 1922. Undoubtedly his "live experience" with the domain of art contributed to art being integrated into scientific actions and into his proposal for education. Vygotsky understands imagination and creativity as being intrinsically related to the development of the superior psychological functions proper to mankind. 
Human imagination is seen as a new formation which has become historically viable, forming part of the system of superior psychological functions. It is considered by Vigotski to be a "more complex form of psychic activity", as "the union of various functions in their peculiar relationships” (Obras escogidas, v. II), and is intrinsically linked to the human capacity of planning and achieving. It is in this sense that Vigotski emphasizes that imagination needs to be completed, i.e., accomplished through an artifact, a word, a work of art; it needs to take on shape, to become a product capable of integrating, in an objective manner, collective production (Smolka in Vigotsky, 2009: p. 30).

According to Vygotsky's cultural-historical theory, creativity is inherent to the human condition, and it is the most important activity because it is the expression of consciousness, thought and language. This aspect of creativity as an inherent factor of the human condition needs to be understood in its socio-historical dimension. In other words, from Vygotsky's point of view all psychic activity occurs in the mediation with the social history of human beings. It is this mediation that contributes to aspects such as creativity, subjectivity and the psychic world itself being immanent and inherent to that which is human, revealing all its historical and social potentiality. Creativity is the highest expression ofsubjectivity (Vygotsky, 2010). Piske (2013) emphasizes that according to Vygotsky creativity can be understood as an innovate psychic process a child develops through its interactions with other subjects in a given social and cultural context. "In focusing on children and adolescents, Vygotsky highlighted the developmental processes that lead to the construction of the new. Play, fantasy, conceptual understanding, and creative imagination are all imbedded in the cultural and social processes that make human life possible" (John-Steiner et al., 2010: p. 14).

According to Vygotsky (2008), a child's imagination develops very early and it is fundamental to nurture this ability because childhood development depends on it. The origin of generalizing thought lies in the imagination. "The creative activity of the imagination is directly related to the richness and diversity of the experiences lived by the subject, because they offer the material for fantasy. This is not necessarily direct experience with the object; hearing accounts of facts experienced by other people, descriptions of objects seen by other eyes or listening to stories of distant cultures are also rich material for building ideas” (Oliveira \& Stoltz, 2010: p. 83).

For Vygotsky $(1994,1996)$, the development of thought is related to the integration between concrete and abstract. Starting with imagination in games and children's toys, which inverts action, so that meaning determines action, Vygotsky argues that childhood games later become an adolescent's fantasy. Visual thinking, which is very important in the development of the intellect, ceases when concepts are formed, but its function continues in the realm of fantasy, where it plays an important role. Visual thinking undergoes important transformations under the influence of concepts, which cannot be excluded from the activity of imagination. It is precisely the intellect and the imagination coming closer to each other that distinguishes the adolescent age. It is in adolescence that thinking aided by metaphors becomes possible. "The movement from the concrete through the abstract to the construction of a new form of a concrete image, is the path which describes imagination in the adolescent age” (Vygotsky, 1994: p. 283).

Fantasy is exemplified by Vygotsky as the creative nature of concrete expression in the construction of a new image. Its high point is the achievement of a concrete form, but this can only be obtained with the help of abstraction. "An adolescent's fantasy moves from the concrete visual image through a concept to an imaginary image" (p. 283). It is through fantasy, one of the manifestations of mankind's creative activity, that adolescents find an effective means of finding a direction for their emotional life and dealing with it. Adolescents find in fantasy a means expressing their rich emotional life and their impulses. The unexpressed parts of adolescents' lives are expressed in creative images.

And now, whilst subjecting imagination to an analysis, we are, once again, able to see how these new forms of behaviour, which have their origins during the time of puberty and the yearnings which are bound up with it, begin to serve the adolescent's emotional strivings, how the adolescent's emotional and intellectual aspects of behaviour achieve their synthesis in his creative imagination, and how longings and thinking become combined in a complicated new way, in the activity connected with the creative imagination (Vygotsky, 1994: p. 286).

Vygotsky notes that all inventors, even geniuses, are always the result of their time and milieu. Their creativity originates from needs that were created before they were and rests upon possibilities that exist in the social and cultural environment (Stoltz \& Piske, 2012). This indicates the social origin of development. The internali- 
zation of shapes mediated by signs constitutes the essential character of superior psychological functions (Vygotsky, 2000). Internalization, as the passage frominter psychic processes to intrapsychic processes, constitutes the essential human data. The passage is accompanied by the production of meanings, fruit of individual activity based on socially shared meanings and involving emotional experience. Creativity lies in this negotiation with culture and production of meaning. Consciousness and subjectivity, as well as the development of concepts are the result of the process of internalization, culminating in live emotional experience which depends on creativity (Stoltz, 2010). In this sense, education, by creating zones of proximal development in a process of relationships, spans the social and the individual, context and experience, enabling new creative syntheses (Stoltz \& Piske, 2012). As such, the new psychological functions need the support of the context, beyond intellectualism (Vygotsky, 1994: p. 274), for the negotiation of meanings and the production of senses.

\section{Conclusion}

In conclusion, both for Vygotsky and for Piaget the environment is of fundamental importance for the development of creative potential. For one of them, Piaget, the importance of the environment is expressed in the interactions that enable the processes of thinking and intelligence to be built. For the other, Vygotsky, the environment appears as a condition that enables social influences to be revealed and contributes to the historical construction of the subjective aspects. As such, it could be said that in Piaget creativity is emphasized in the cognitive aspects, while in Vygotsky creativity can be perceived in the variations in historical and social contexts and this, in turn, shows the potential of changes and adaptations present in the processes of human creation and innovation. In the environment a person has experiences and takes on new instruments which provoke curiosity, the desire to learn, and awaken fantasy and the imagination.

This is why it is important for teachers, as the main mediators in schools, to work with emotion and knowledge and to enable gifted students to share their high abilities with their peers, undertaking activities that are both challenging and also develop sensitivity, within a stimulating environment that responds to their special educational needs, which are not only intellectual but also affective and social.

The debate between Piaget and Vygotsky regarding creativity is highly productive given that it brings essential elements for the challenges of current day education, which needs to go beyond its intellectualist nature and integrate scientific creations with artistic creations. This is equivalent to developing sensitive rationale, where cognition and affectivity are integrated and "live emotional experiences" can come to the fore and enable, along with the development of individual consciousness, greater sensitivity regarding serious social and environmental problems. In the words of Vygotsky (1999), art can integrate affectivity and cognition, providing equilibrium between body and environment. There is much to be done in this sense in education.

\section{References}

Alencar, E. M. L. S. (2001). Criatividade e educação de superdotados. Petrópolis, RJ: Vozes.

Alencar, E. M. L. S. (2007). Características socioemocionais do superdotado: questões atuais. Psicologia em Estudo (Online), 12, 371-378. http://dx.doi.org/10.1590/S1413-73722007000200018

Alencar, E. M. L. S. (2009). Como desenvolver o potencial criador: Um guia para a liberação da criatividade em sala de aula. Petrópolis, RJ: Vozes.

Alencar, E. M. L. S. (2011). Criatividade na educação superior na perspectiva de estudantes e professores. In S. M. Wechsler, \& T. C. Nakano (Orgs.), Criatividade no ensino superior: Uma perspectiva internacional (pp. 180-201). São Paulo: Vetor.

Bringuier, J. C. (1978). Conversando com Jean Piaget. Rio de Janeiro e São Paulo: Difel.

Gruber, H., \& Vonèche, J. J. (Eds.) (1995). The essential Piaget. An Interpretive Reference and Guide. New Jersey: Aronson.

John-Steiner, V., Connery, M. C., \& Marjanovic-shane, A. (2010). Dancing with the Muses: A Cultural-Historical Approach to Play, Meaning Making and Creativity. In M. C. Connery, V. John-Steiner, \& A. Marjanovic-Shane (Eds.), Vygotsky and Creativity. A Cultural-Historical Approach to Play, Meaning Making, and the Arts. New York: Peter Lang.

Marjanovic-Shane, A., Connery, M. C., \& John-Steiner, V. A. (2010). Cultural-Historical Approach to Creative Education. In M. C. Connery, V. John-Steiner, \& A. Marjanovic-Shane (Eds.), Vygotsky and Creativity. A Cultural-Historical Approach to Play, Meaning Making, and the Arts. New York: Peter Lang.

Oliveira, M. E. de., \& Stoltz, T. (2010). Teatro na escola: Considerações a partir de Vygotsky. Educar em revista, Curitiba, 36, 77-93. http://www.scielo.br/scielo.php?script=sci arttext\&pid=S0104-40602010000100007\&lng=en\&nrm=iso 
http://dx.doi.org/10.1590/S0104-40602010000100007

Pérez, S. G. P. B. (2004). Gasparzinho vai à escola: Um estudo sobre as características do aluno com altas habilidades produtivo-criativo. Dissertação (Mestrado em Educação), Porto Alegre: Pontifícia Universidade Católica do Rio Grande do Sul,

Peterson, J. S. (2003). Underachievers: Students Who Don’t Perform. In J. F. Smutny (Ed.), Underserved Gifted Populations (pp. 307-332). Creskill, NJ: Hampton.

Piaget, J. (1936). La naissance de l'intelligence chezl'enfant. Neuchâtel: Delachaux et Niestlé.

Piaget, J. (1937). La construction du réelchezl'enfant. Neuchâtel: Delachaux et Niestlé.

Piaget, J. (1964). Cognitive Development in Children: Development and Learning. Journal of Research in Science Teaching, 2, 176-186. http://dx.doi.org/10.1002/tea.3660020306

Piaget, J. (1974a). La prise de conscience. Paris: PUF.

Piaget, J. (1974b). Réussir et comprendre. Paris: PUF.

Piaget, J. (1978). A formação do símbolo na criança: Imitação, jogo, sonho, imagem e representação (3rd ed.). Rio de Janeiro: Zahar.

Piaget, J. (2000). Para onde vai a educação (15th ed.)? Rio de Janeiro: José Olympio.

Piaget, J. (2003). Biologia e conhecimento. Ensaio sobre as relações entre as regulações orgânicas e os processos cognoscitivos (4th ed.). Petrópolis, RJ: Vozes.

Piaget, J., \& Inhelder, B. (2003). A psicologia da criança. Rio de Janeiro: Difel.

Piske, F. H. R. (2011). Diversidade e inclusão: O direito à educação de alunos superdotados. X Congresso Nacional de Educação-Educere-I Seminário Internacional de Representações Sociais, Subjetividade e Educação—SIRSSE. Curitiba: Pontifícia Universidade Católica do Paraná, 151-161. http://educere.bruc.com.br/CD2011/pdf/4341_2306.pdf

Piske, F. H. R. (2013). O desenvolvimento socioemocional de alunos com altas habilidades/superdotação (AH/SD) no contexto escolar: Contribuições a partir de Vygotsky. Dissertação (Mestrado em Educação). Curitiba: Universidade Federal do Paraná.

Piske, F. H. R., \& Stoltz, T. (2012). O desenvolvimento afetivo de alunos superdotados: Uma contribuição a partir de Piaget. Schème: Revista Eletrônica de Psicologia e Epistemologia Genéticas, 4, 149-166.

Piske, F. H. R., \& Stoltz, T. (2013). Criatividade na escola: A necessidade de reavaliar as práticas educacionais aos alunos superdotados. In F. H. Piske, \& S. Bahia (Coods.), Criatividade na escola: O desenvolvimento de potencialidades, altas habilidades/superdotação (AH/SD) e talentos. Curitiba: Juruá.

Piske, F. H. R., Stoltz, T., \& Machado, J. (2014a). Creative Education for Gifted Children. Creative Education, 5, $347-352$. http://www.scirp.org/journal/PaperInformation.aspx?PaperID=45206

Piske, F. H. R., Stoltz, T., \& Machado, J. (2014b). Creative Educational Practices for Inclusion of Gifted Children. Creative Education, 5, 803-808. http://www.scirp.org/journal/PaperInformation.aspx?PaperID=46997

Prieto, M. D., Soto, G., \& Fernández, M. C. (2013). El aula como espacio creativo. In F. H. Piske, \& S. Bahia (Coods.), Criatividade na escola: O desenvolvimento de potencialidades, altas habilidades/superdotação (AH/SD) e talentos. Curitiba: Juruá.

Renzulli, J. S. (2004). O que é esta coisa chamada superdotação, e como a desenvolvemos? Uma retrospectiva de vinte e cinco anos. Educação, 27, 75-131.

Stoltz, T. (2010). Por que Vygotsky na educação? In E. C. Ramos, \& K. Franklin (Orgs.), Fundamentos da educação: Os diversos olhares do educar. Curitiba: Juruá.

Stoltz, T. (2013). Desenvolvimento cognitivo como invenção e para além da racionalidade. In F. H. R. Piske, \& S. Bahia (Eds.), Criatividade na escola: O desenvolvimento de potencialidades, altas habilidades/superdotação (AH/SD) e talentos. Curitiba: Juruá.

Stoltz, T., \& Parrat-Dayan, S. (2012). Imaginário criativo e racionalidade: Incompatibilidade ou compatibilidade? In L. C. Moreira, \& T. Stoltz (Orgs.), Altas habilidades/superdotação, talento, dotação e educação. Curitiba: Juruá.

Stoltz, T., \& Piske, F. H. R. (2012). Vygotsky e a questão do talento e da genialidade. In L. C. Moreira, \& T. Stoltz (Orgs.), Altas habilidades/superdotação, talento, dotação e educação. Curitiba: Juruá.

Stoltz, T., \& Weger, U. (2012). Piaget and Steiner: Science and Art in the Process of Formation. Research on Steiner Education (RoSE), 3, 134-145. Oslo: Rudolf Steiner University College; Alfter: Alanus University of Arts and Social Sciences.

http://www.rosejourn.com/index.php/rose/article/viewFile/106/131

Van Der Veer, R., \& Valsiner, J. (2009). Vygotsky: Uma síntese (6th ed.). São Paulo: Edições Loyola.

Vonèche, J., \& Stoltz, T. (2007). Ação como solução ao problema mente e corpo na teoria de Piaget. Educar em Revista, 30, 
17-43. http://www.scielo.br/scielo.php?script=sci_arttext\&pid=S0104-40602007000200003\&lng=en\&nrm=iso http://dx.doi.org/10.1590/S0104-40602007000200003

Vygotsky, L. S. (1994). Imagination and Creativity of the Adolescent. In R. Van Der Veer, \& J. Valsiner (Eds.), The Vygotsky Reader. Hoboken NJ: Blackwell.

Vygotsky, L. S. (1996). Obras Escogidas. Vol. 4, Psicología Infantil. Madrid: Visor.

Vygotsky, L. S. (1999). Psicologia da arte. São Paulo: Martins Fontes.

Vygotsky, L. S. (2000). A construção do pensamento e da linguagem. São Paulo: Martins Fontes.

Vygotsky, L. S. (2008). A formação social da mente. São Paulo: Martins Fontes.

Vygotsky, L. S. (2009). Imaginação e criação na infância: Ensaio psicológico. Livro para professores. Apresentação e comentários Ana Luiza Smolka. São Paulo: Ática.

Vygotsky, L. S. (2010). Psicologia Pedagógica. São Paulo: Martins Fontes.

Winner, E. (1998). Crianças superdotadas: Mitos e realidades. Porto Alegre: Artes Médicas. 
Scientific Research Publishing (SCIRP) is one of the largest Open Access journal publishers. It is currently publishing more than 200 open access, online, peer-reviewed journals covering a wide range of academic disciplines. SCIRP serves the worldwide academic communities and contributes to the progress and application of science with its publication.

Other selected journals from SCIRP are listed as below. Submit your manuscript to us via either submit@scirp.org or Online Submission Portal.
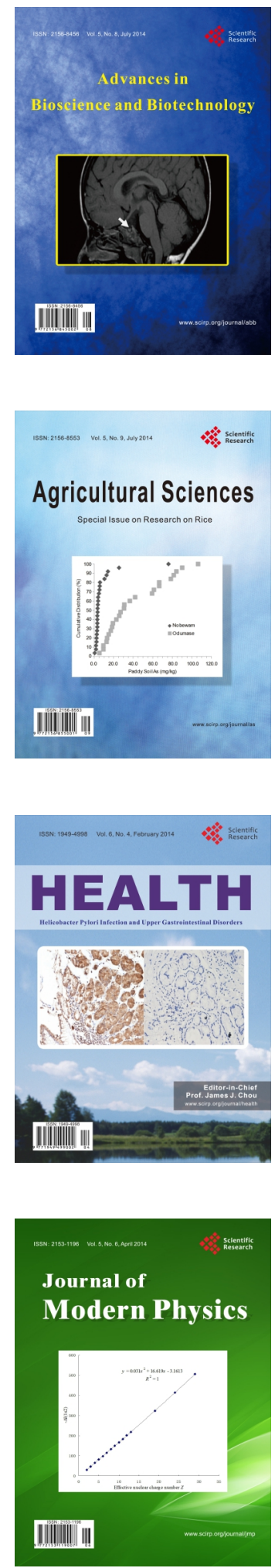
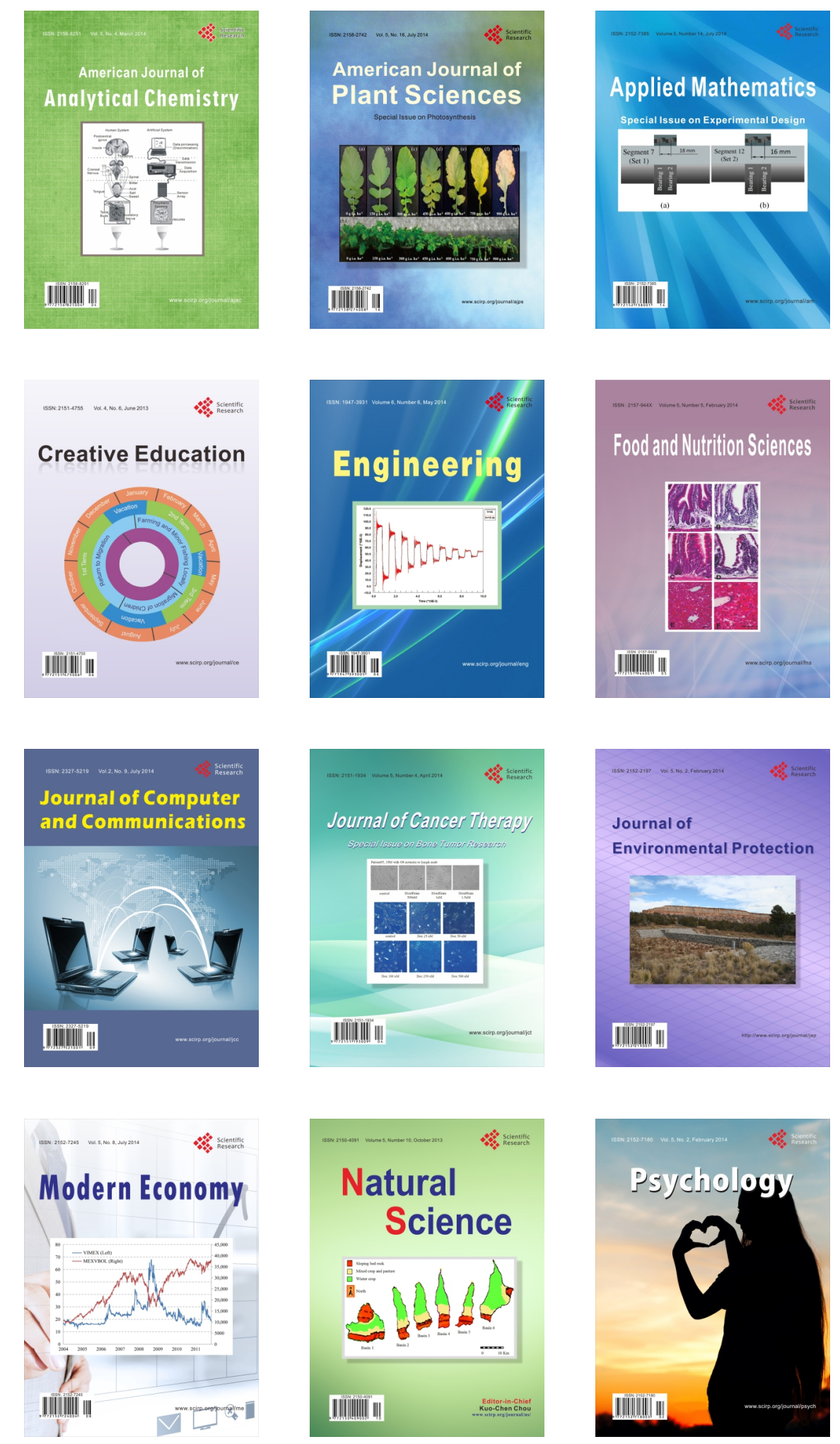